【論文】

\title{
熱電素子を用いた温度変化センサの試作 ならびに水中投入時の応答評価 \\ Development of the Temperature-Change Sensor by Thermoelectric Elements and Response Evaluation on Dropping into Water
}

\author{
田中勝之*，安野拓也，東之弘，奥崎俊一**，片倉辰男 \\ Katsuyuki TANAKA, Takuya YASUNO, Yukihiro HIGASHI, \\ Shunichi OKUZAKI, and Tatsuo KATAKURA
}

\begin{abstract}
$\mathrm{p}$ 型と $\mathrm{n}$ 型の熱電素子を直接接合した構造の温度変化センサ(熱電温度変化センサ)を提案し, 試作し た．試作したセンサの熱電素子には，高いゼーベック効果がある放電プラズマ焼結法で作製した $\beta-\mathrm{FeSi}_{2}$ 系熱電半導体を用いた. この熱電温度変化センサの特性を評価するため, センサを室温から温 度差のある恒温水槽へ投入したときのセンサからの起電力を測定し, 温度差と起電力との相関関係か ら温度変化センサとして機能することを確認した。このとき，約 $30 \mathrm{~K}$ の温度差に対して，約 $5 \mathrm{mV} の$ 最大起電力が得られた. さらに, 熱電温度変化センサの特性を数值解析によって, 熱電素子の長さや直 径などの形状の依存性とゼーベック係数や熱伝導率, 密度, 比熱などの物性值の依存性を明らかにした.
\end{abstract}

The temperature-change sensor by thermoelectric module jointed directly $\mathrm{p}$ type element and $\mathrm{n}$ type element was developed. $\beta$ - $\mathrm{FeSi}_{2}$ thermoelectric semiconductor made by spark plasma sintering method was used for the prototype sensor. Evaluation of this thermoelectric temperature-change sensor was carried out by measuring electromotive force on dropping into the isothermal water bath. It is confirmed that there is a correlation between temperature difference and electromotive force of the sensor, about $5 \mathrm{mV}$ of electromotive force was generated by $30 \mathrm{~K}$ of temperature difference. Additionally, dependence of electromotive force on size and thermophysical properties of thermoelectric elements was evaluated by FEM analysis.

[Keywords: Temperature-difference sensor, thermoelectric semiconductor, $\beta$-FeSi ${ }_{2}$ ]

\section{1.はじめに}

熱電素子は，熱エネルギーを電気エネルギーに，あるいは 電気エネルギーを熱エネルギーに直接変換できるものであ り，それを用いた熱電モジュールは，排熱発電機[1]や小型冷 却器[2]への応用が進められている. 熱電モジュールの一般的 な構造は, 図 1 に示寸ように $\mathrm{p}$ 型熱電素子と $\mathrm{n}$ 型熱電素子が 対となって電気的に直列に接続されたものであり，熱電モジ ユールの上面と下面との間に温度差を与えるとゼーベック 効果によって起電力が生じ, 逆に熱電モジュールに電流を通

* いわき明星大学科学技術学部システムデザイン工学科, 下970-8551 福島県いわき市中央台飯野5-5-1.

Dept. of Mechanical Systems and Design Engineering, Iwaki Meisei University, 5-5-1 lino, Chuodai, Iwaki, Fukushima, 970-8551.

FAX: 0246-29-0577 E-mail: ktanaka@iwakimu.ac.jp

** 沖電気防災株式会社商品開発部,

T960-1101 福島県福島市大森字日ノ下 9-1.

Dept. of Product-Development, Oki Denki Bohsai, Co., Ltd., 9-1 Hinoshita, Oomori-aza, Fukushima, 960-1101.

FAX: 024-544-2195 E-mail: okuzaki@okibo.co.jp
すとペルチェ効果によって熱電モジュールの上面と下面と の間に温度差が生じるものである. この特性を利用して, 両 端の温度差に対寸る起電力の関係をあらかじめ校正してお くことで, 熱電モジュールは温度変化センサとしても用いる ことができる.

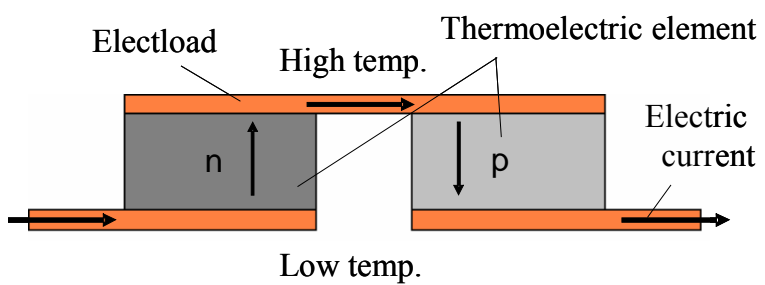

Fig.1 Typical structure of thermoelectric module

温度変化センサとして利用が期待されるのは, 空調装置や プラント，火災報知設備などが挙げられる. 従来の温度変化 センサには，サーミスタを用いた抵抗值の変化を検出する夕 イプ, バイメタルによる物理的な形状変化を利用したタイプ, 密閉した空気の膨張による圧力変化を利用したタイプ, 熱電 モジュールと同様にゼーベック効果を利用した熱電対が挙 
げられる. サーミスタを用いたタイプは検出するための複雑 な回路を必要とし, バイメタルや空気膨長を用いたタイプは 構造が複雑で台風などの物理的影響を受けやすく, 熱電対を 用いたタイプは起電力が小さく, 熱容量が小さいため電気的 ノイズの影響を受けやすいという問題点がある. そこで，高 いゼーベック係数を示寸 $\mathrm{FeSi}_{2}$ 系熱電半導体[3]に注目して著 者らが開発を進めている $\beta-\mathrm{FeSi}_{2}$ 系熱電半導体[4]の利用を考 えた. この熱電半導体は, 原材料の費用が低 $<$, 機械的強度 に優れるため, 市販の熱電モジュールに用いられている素子 に比べて大きいサイズで熱容量の大きな安定性のある素子 を作製することができ, 温度変化センサとしての用途に最適 である. しかしながら, 図 1 に示した一般的なモジュール構 造では, 表面における温度差の検知用に限られ, 空調装置や 火災感知器のように空間における温度差を検知することが 難しい，そこで本研究では， $\mathrm{p}$ 型と $\mathrm{n}$ 型の熱電素子を直接接 合させて接合面がモジュール内部になる構造とし，モジュー ル周囲の温度変化によって生じるモジュールの内部と周囲 との温度差により起電力を発生させる温度変化セン少(熱電 温度変化センサ)を提案し, 試作とその特性評価を行なった。

\section{2. 熱電温度変化センサの動作原理}

図 2 に熱電温度変化センサの概念図を示す. $\mathrm{p}$ 型と $\mathrm{n}$ 型の熱 電素子を直接接合し,その両端から電極を取り出す構造である.

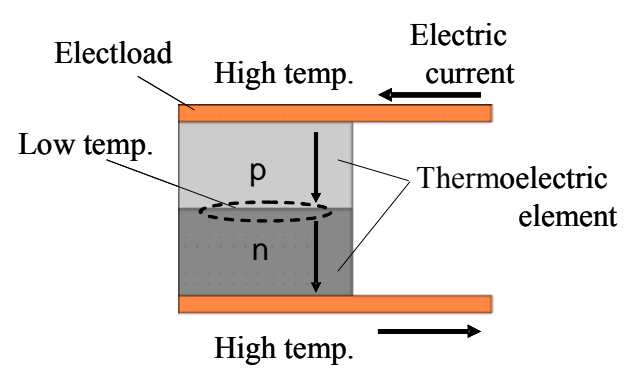

Fig.2 Principle of the thermoelectric temperature-change sensor

センサが熱平衡状態にあるときには起電力は生じないが, センサ周囲の温度が上昇したとき, センサの内部にある $\mathrm{p}-\mathrm{n}$ 接合面の温度が相対的に低くなり, センサの周囲と内部の温 度差によって $\mathrm{p}$ 型と $\mathrm{n}$ 型の熱電素子に起電力が生じ, 図 2 に 示した矢印の向きに電流が流れる仕組みである. また, セン サ周囲の温度が下降したときは，起電力の正負が逆になり， 電流も逆向きになる. そこで, あらかじめ温度差に対する起 電力の特性を調べておくことにより, 温度変化センサとして 用いることができる.

\section{3. 熱電温度変化センサの試作}

図3 に試作した熱電温度変化センサを示す. 熱電素子には $\beta-\mathrm{FeSi}_{2}$ 系熱電半導体を用い, $\mathrm{p}$ 型は $\mathrm{FeSi}_{2}-4.1 \% \mathrm{Cr}, \mathrm{n}$ 型は $\mathrm{FeSi}_{2}-2.4 \% \mathrm{Co}$ を放電プラズマ焼結法により温度 $750^{\circ} \mathrm{C}$, 加圧 力 $35 \mathrm{MPa}$ ，保持時間 $10 \mathrm{~min}$ の焼結条件で作製したもの[4]で あり, $\mathrm{P}$ 型と $\mathrm{N}$ 型共に直径 $20 \mathrm{~mm}$, 長さ $7 \mathrm{~mm}$ の円柱である. この熱電半導体を使い, 図 1 に示した 1 対の構造でのゼーベ ック係数は, 著者らが開発した温度差発生装置[5]を用いて測

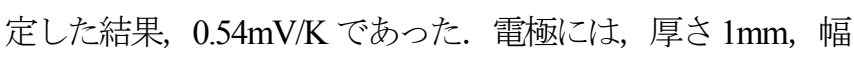
$20 \mathrm{~mm}$ ，長さ $50 \mathrm{~mm}$ の銅製の平板を用いた．熱電素子の接合 ならびに電極との接合には, 熱伝導率が良く, 導電体のシル バー両面粘着シート(応研商事社製)を用いた。

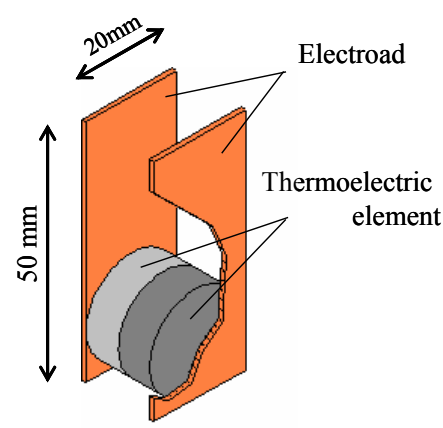

Fig.3 Prototype thermoelectric temperature-change sensor

\section{4. 特性評価装置}

温度変化センサの特性試験は, 室温で熱平衡状態にしたセ ンサを室温よりも高い温度もしくは低い温度の一定温度場 に投入したときのセンサからの起電力を測定し，そのときの 温度差に対する起電力の関係を求める.

図 4 に温度変化センサ特性評価装置を示寸。一定温度場と して，卓上低温恒温水槽(井内盛栄堂社製，CB-15 型，浴槽容 量 $120 \mathrm{~mm} \times 220 \mathrm{~mm} \times 150 \mathrm{~mm}$ )を用いた. その恒温水槽の蓋と してアクリル板を用いて電極端子を取り付け, 蓋の下側から 配線を引き出し, 温度変化センサの電極をワニロクリップで 固定し，吊るすことができる，温度変化センサからの起電力 は，蓋の上側から配線し，デジタルマルチメータ(Keithley， 2000)で測定し， GPIBにより PC 一約 1s のサンプリングタイ プで取り込んだ.また，モジュールの真横に温度測定用の熱 電対( $\mathrm{T}$ 型)を設置し, 冷接点を介した起電力を温度変化セン サと同様に測定し，記録した. 熱電対はいくつかの温度に設 定した恒温水槽と付け合せて校正を行った. 図 5 に熱電対の 起電力に対する温度の関係を示す，これより，熱電対の起電 
力に対する温度を 1 次式で相関し, 最小二乗法により, 式(1) を得た。

$$
T /{ }^{\circ} \mathrm{C}=24.997 \times(E / \mathrm{mV})
$$

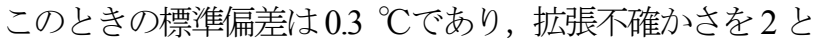
して熱電対の温度測定不確かさを $\pm 0.6{ }^{\circ} \mathrm{C}$ と見積った.

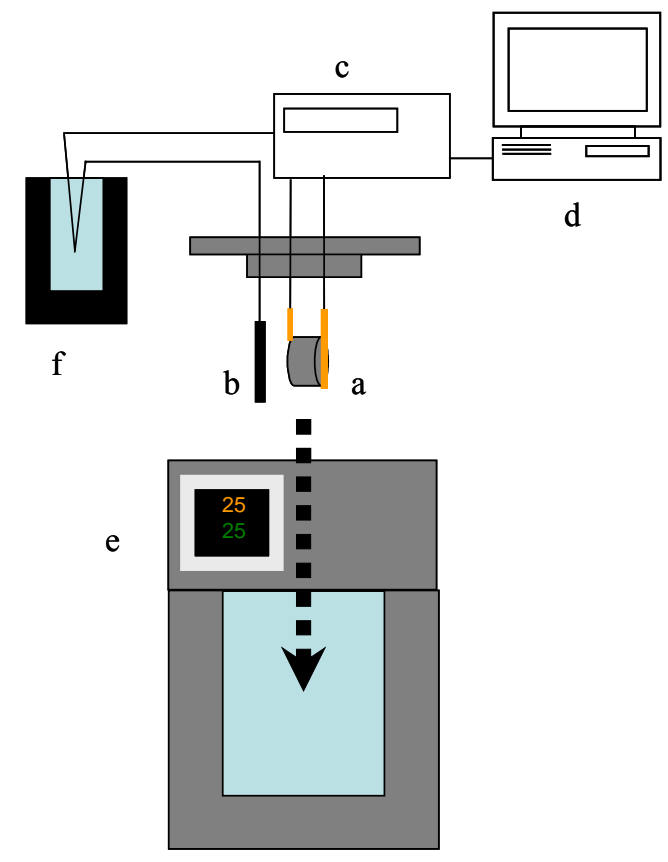

Fig.4 Schematic diagram of an apparatus for evaluation of the temperature-change sensor;
a: thermoelectric temperature-change sensor,
b: thermocouple for measuring temperature,
c: digital multi-meter, d: computer,
e: isothermal water bath, f: cold junction

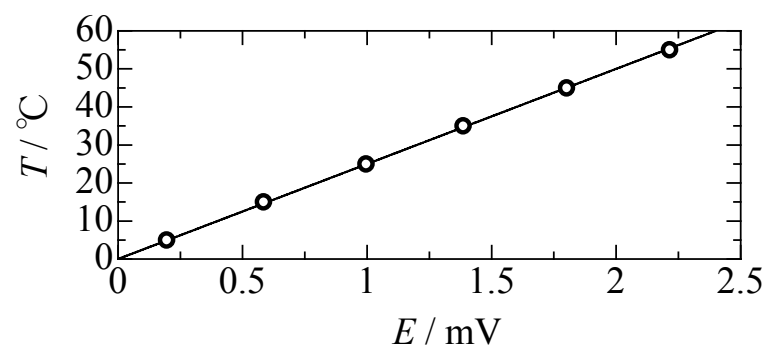

Fig.5 Relationship between temperature and electromotive force of thermocouple

\section{5. 熱電温度変化センサの特性}

試作した熱電温度変化センサについて前述の特性評価装 置を用い，恒温水槽の温度を室温より低い $5^{\circ} \mathrm{C}$ と高い $25^{\circ} \mathrm{C}$ ら $55^{\circ} \mathrm{C}$ までの $10^{\circ} \mathrm{C}$ おきに設定し, 恒温水槽の温度と室温か
らの温度差に対する温度変化センサからの起電力を測定し た. 代表的な測定例として恒温水槽を $45^{\circ} \mathrm{C}$ に設定したときの データを図 6 に示寸. 図 6 の(a)は，温度変化センサを恒温水 槽へ投入した後の経過時間に対する熱電対による測定温度 である．初期温度の室温は，センサを恒温水槽へ投入前の

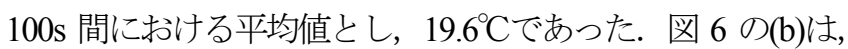
温度変化センサからの起電力であり, 恒温水槽一投入後の約 5 秒で最大電圧 $4.39 \mathrm{mV}$ を示し, その後温度変化センサ内部 の温度上昇にともない，出力はゆっくりと減衰し，約 40 秒 後には 0V に戻り，その後，負の電圧を示し-0.17mV で安定 した. このときの温度差 $25.4 \mathrm{~K}$ と最大起電力 $4.39 \mathrm{mV}$ を用い て単位温度差あたりの起電力を求めると $0.17 \mathrm{mV} / \mathrm{K}$ となり, ゼーベック係数の $0.54 \mathrm{mV} / \mathrm{K} の 30 \%$ 程の值となった.これは, ゼーベック係数の測定が定常状態で行われることにより, 温 度差が一定に保たれていることに対し，温度変化センサにお いては非定常状態であり，同時に内部の温度が上昇している からであると考えられる. また，起電力が負の值に収束した ことは, センサの内部の方が外側よりも高い温度であること を示し，センサの外側にある電極から恒温水槽の外部一の熱 損失が原因と考えられる.
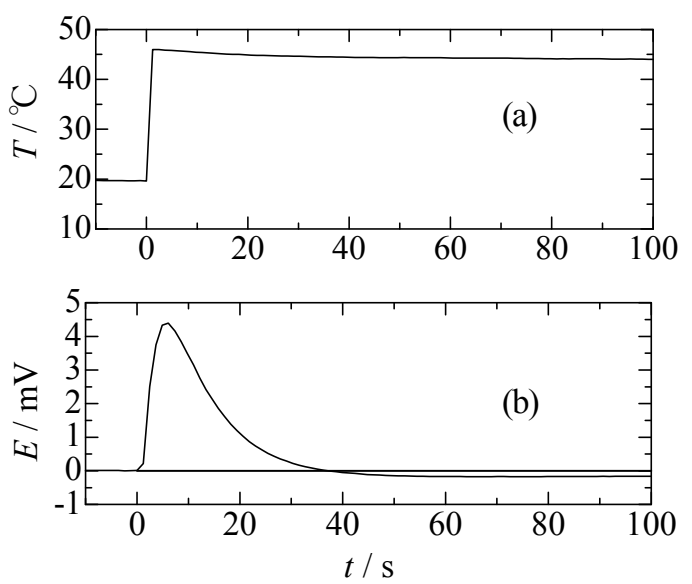

Fig.6 Measurement data;

(a) Temperature change, (b) Electromotive-force change

各設定温度の恒温水槽に温度変化センサを投入した際の その起電力の経時変化について断熱なしの場合を図7に示寸。 また，そのときの恒温水槽の設定温度 $T_{\mathrm{b}}$ と初期温度 $T_{0}$, 温 度差 $\Delta T$, 温度変化センサの最大起電力 $E_{\max }$ および最大起電 力を示した投入後の経過時間 $t_{\mathrm{m}}$ を表 1 に示寸. 温度差が大き くなるにつれて起電力も大きくなり, 恒温水槽の温度が室温 より低い場合は，負の起電力を示し，動作原理に基づく結果 が得られた. また, 最大起電力に達する時間や起電力が $0 に$ 戻る時間は, サンプリング間隔(約 1.2 秒)内で一致し, 温度 差に依存しなかった。 


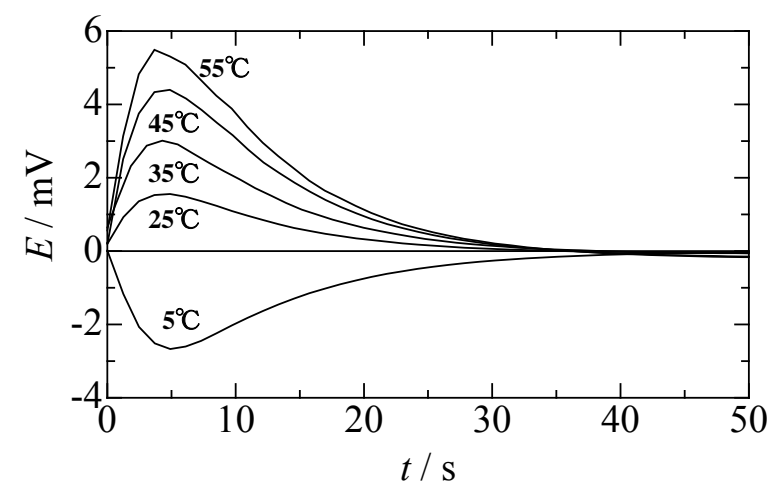

Fig.7 Electromotive-force change at each temperature of isothermal bath

Table 1 Experimental result of electromotive force

\begin{tabular}{ccccc}
\hline $\begin{array}{c}T_{\mathrm{b}} \\
{\left[{ }^{\circ} \mathrm{C}\right]}\end{array}$ & $\begin{array}{c}T_{0} \\
{\left[{ }^{\circ} \mathrm{C}\right]}\end{array}$ & $\begin{array}{c}\Delta T \\
{[\mathrm{~K}]}\end{array}$ & $\begin{array}{c}E_{\max } \\
{[\mathrm{mV}]}\end{array}$ & $\begin{array}{c}t_{\mathrm{m}} \\
{[\mathrm{s}]}\end{array}$ \\
\hline 5 & 20.4 & -15.4 & -2.67 & 5 \\
25 & 19.6 & 5.4 & 1.56 & 5 \\
35 & 19.6 & 15.4 & 3.01 & 5 \\
45 & 19.6 & 25.4 & 4.39 & 5 \\
55 & 19.2 & 35.8 & 5.49 & 4 \\
\hline
\end{tabular}

図 8 に最大起電力に対する温度差の関係を示す. 温度差は 最大起電力に対して式(2)に示すように相関することができた.

$$
\Delta T_{\max } / \mathrm{K}=0.343\left(E_{\max } / \mathrm{mV}\right)^{2}+5.27\left(E_{\max } / \mathrm{mV}\right)-3.75
$$

このときの標準偏差は $0.3 \mathrm{~K}$ であり, 拡張不確かさを 2 とし て, 温度差測定不確かさが $\pm 0.6 \mathrm{~K}$ の熱電温度変化センサと して機能することが確認できた.

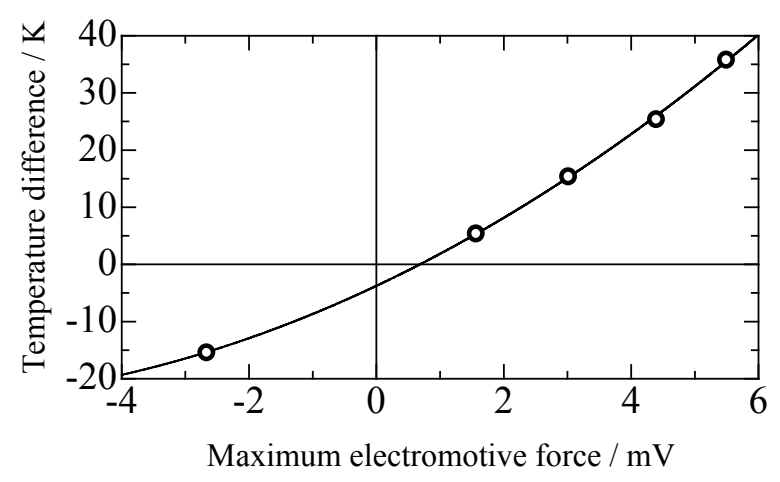

Fig.8 Relationship between temperature difference and maximum electromotive force

\section{6. 熱電温度変化センサの数值解析}

熱電半導体を用いた熱電温度変化センサの利点として, 素 子を比較的大きく作製できるため, 形状の設定に自由度があ
り，用途に合う特性を持つセンサに設計できる。しかしなが ら，そのような温度変化センサを模索するにあたり，試行錯 䛊でセンサを試作寸ることになると非常に手間がかかる. そ こで, FEM 解析の汎用ソフトウェアである ANSYS を用いて 熱電温度変化センサの特性をシミュレーションし, 形状や物 性值に対する温度変化センサの特性の変化を数值解析によ って明らかにする.

\section{1 計算方法}

本研究で試作した温度変化センサに用いた円柱型の熱電 素子の形状（p 型と $\mathrm{n}$ 型共に直径 $20 \mathrm{~mm}$ ，長さ $7 \mathrm{~mm}$ ），銅製 の電極の厚さ $1 \mathrm{~mm}$ を基本とし, 図 9 に示寸ように軸対象の 2 次元平面の計算モデルを作成した. 計算モデルの各要素に は, 伝熱と電場の連成場による設定が可能であり, 温度変化 センサ内の温度分布ならびに電位分布を計算することがで きる. 図 10 および図 11 に最大起電力発生時の温度分布と電 位分布の計算例を示寸. 実験データの起電力と比較するため, 計算モデルの起電力は, 一方の電極における電位を基隻とし て 0Vに設定し，もう一方の電極における電位の值とした.

計算に用いた $\beta-\mathrm{FeSi}_{2}$ 系熱電半導体ならびに電極で用いた銅 の物性值を表 2 に示寸. ここで, $\beta$ - $\mathrm{FeSi}_{2}$ 系熱電半導体の物性 值について，ゼーベック係数は 1 対での測定值 $0.54 \mathrm{mV} / \mathrm{K}$ を 用いて $\mathrm{p}$ 型と $\mathrm{n}$ 型をそれぞれ $0.27 \mathrm{mV} / \mathrm{K}$ と- $0.27 \mathrm{mV} / \mathrm{K}$ とした. 密度は電子天秤で測定した質量と寸法の測定值から得た值 $4 \mathrm{~g} / \mathrm{cm}^{3}$ を用いた。 熱伝導率と電気抵抗率は，文献值を用いた [6]. 比熱の值は文献值からも得ることが出来なかったため, その值を逐次変化させてシミュレーションを繰り返し, 実験 データに合うように決定した值を用いた．また，銅の物性值 についてはすべて文献值を用いた[6].

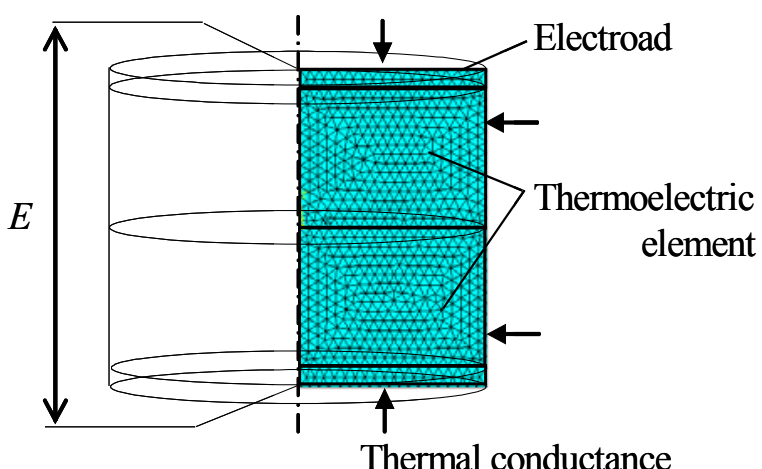

Fig.9 Model of the thermoelectric temperature-change sensor for FEM analysis 


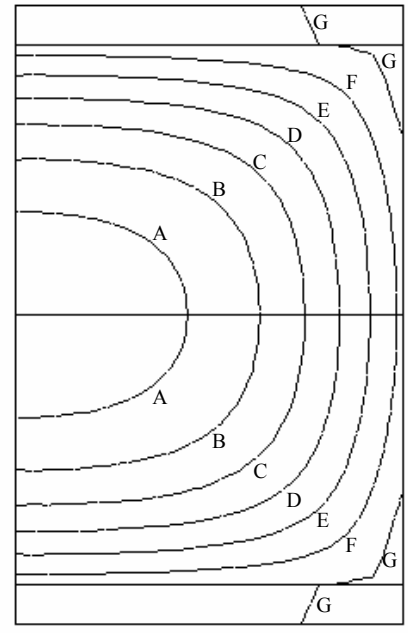

Fig.10 Distribution of the temperature at a peak of electromotive force;

A: $22{ }^{\circ} \mathrm{C}, \mathrm{B}: 24^{\circ} \mathrm{C}, \mathrm{C}: 26{ }^{\circ} \mathrm{C}, \mathrm{D}: 28^{\circ} \mathrm{C}, \mathrm{E}: 30^{\circ} \mathrm{C}$, F: $32{ }^{\circ} \mathrm{C}, \mathrm{G}: 34{ }^{\circ} \mathrm{C}$

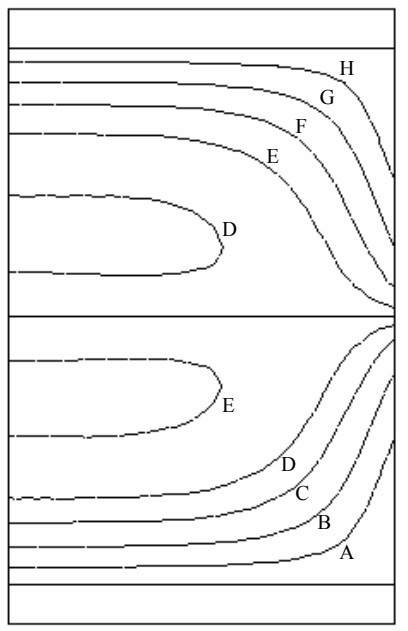

Fig.11 Distribution of the electric potential at a peak of electromotive force;

A: $0.5 \mathrm{mV}, \mathrm{B}: 1.0 \mathrm{mV}, \mathrm{C}: 1.5 \mathrm{mV}, \mathrm{D}: 2.0 \mathrm{mV}$,

E: $2.5 \mathrm{mV}, \mathrm{F}: 3.0 \mathrm{mV}$, G: $3.5 \mathrm{mV}$, H: $4.0 \mathrm{mV}$

Table 2 Material properties for FEM analysis

\begin{tabular}{l|l|l}
\hline Material properties & $\mathrm{FeSi}_{2}$ & $\mathrm{Cu}$ \\
\hline Density $\left[\mathrm{kg} / \mathrm{m}^{3}\right]$ & $4 \times 10^{3}$ & $8.9 \times 10^{3}$ \\
\hline $\begin{array}{l}\text { Specific heat } \\
{[\mathrm{J} /(\mathrm{kg} \cdot \mathrm{K})]}\end{array}$ & 1300 & 386 \\
\hline $\begin{array}{l}\text { Thermal conductivity } \\
{[\mathrm{W} /(\mathrm{m} \cdot \mathrm{K})]}\end{array}$ & 12 & 398 \\
\hline $\begin{array}{l}\text { Electrical resistivity } \\
{[\Omega \cdot \mathrm{m}]}\end{array}$ & $7.7 \times 10^{-5}$ & $1.6 \times 10^{-8}$ \\
$\begin{array}{l}\text { Seebeck coefficient } \\
{[\mathrm{mV} / \mathrm{K}]}\end{array}$ & $0.27(\mathrm{P})$ & - \\
\hline
\end{tabular}

\section{2 実験データとの比較}

試作したセンサと同じ寸法でモデリングを行い，恒温水槽 の温度 $45^{\circ} \mathrm{C}$ に設定した測定データと同じ初期条件の室温 $19.6^{\circ} \mathrm{C}$ で計算を行った. ここで，境界条件である恒温水槽とセ ンサとの熱伝達係数は未知数であったため，比熱の值と共に 熱伝達係数の值を逐次変化させてシミュレーションを繰り返 して実験データに合うように決定し，2900W/( $\left.\mathrm{m}^{2} \cdot \mathrm{K}\right)$ となった. 実験デー夕と数值解析デー夕の起電力の経時変化を図 12 に示 す. 実験データでは, 初めの立ち上がりに遅れが生じており， 数值解析データと 2 秒程度の差があったが，実験データには 恒温水槽への投入操作による遅れや，データのサンプリング 間隔(約 1.2 秒)の影響が生じているためであると考える. また, 実験データでは起電力が 0 に戻った後，負の值を示している のに対し，数值解析データでは 0 に収束している.これは, 先に述べたように電極から恒温水槽外部への熱損失の影響と 考えられるが，微小であるので数值解析では無視した。 しか しながら，数值解析データによる起電力の経時変化の挙動は 実験データを良く再現しており，熱電素子の形状や物性值を 変えた場合の変化を検討するには，十分であると考える.

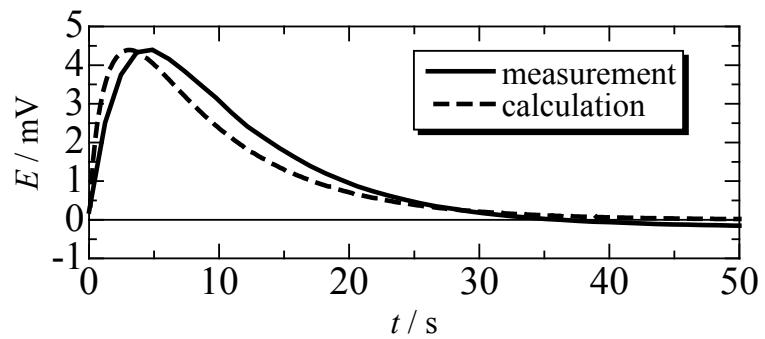

Fig.12 Comparison of electromotive force change between the calculation data and the measurement data

\section{3 温度変化センサの形状依存性}

試作したセンサに用いた熱電素子の寸法（直径 $20 \mathrm{~mm}$ ，長 さ $7 \mathrm{~mm}$ ）を基準として，電極や恒温水槽温度，初期条件， 境界条件を固定したまま長さのみを 0.5 倍と 2 倍とした場合 における起電力の経時変化の計算結果を図 13 に示寸. 同様 にして直径のみを 0.5 倍と 2 倍とした場合における起電力の 経時変化の計算結果を図 14 に示寸，また，それぞれの計算 結果における最大起電力の值の関係を基準寸法と比較して 図 15 に示す，熱電素子の長さおよび直径を大きくする程， 最大起電力は大きくなるが，図 15 に示したように長さの方 が最大起電力に与える影響は大きいことが分かる。ただし， 図 16 に示寸ように熱電素子の体積で比較すると，直径は 2 乗で効いてくるため，起電力を高くしたい場合は，コストの 面を考慮すると，長さを大きくする方が良いことが分かる. 


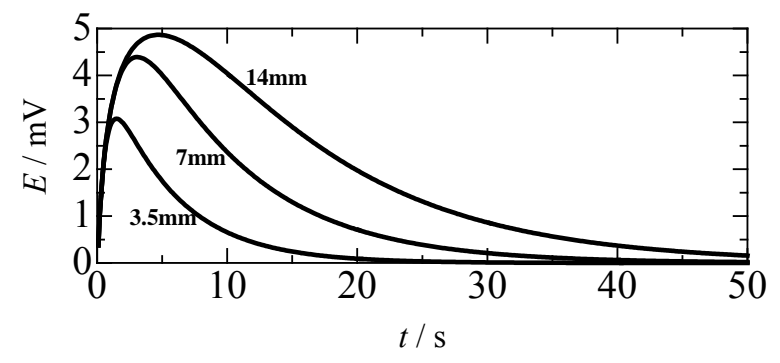

Fig.13 Comparison of electromotive force change in different length of thermoelectric element

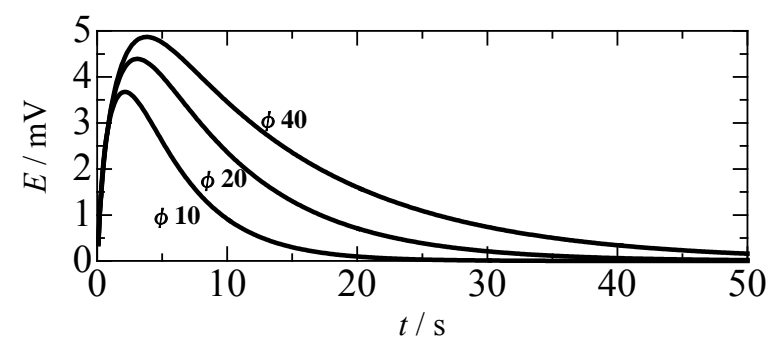

Fig.14 Comparison of electromotive force change in different diameter of thermoelectric element

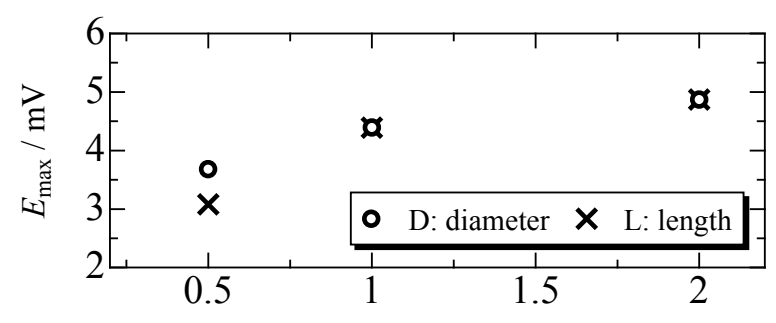

ratio of length and diameter to reference value

Fig.15 Maximum electromotive force against the ratio of length and diameter to the reference value

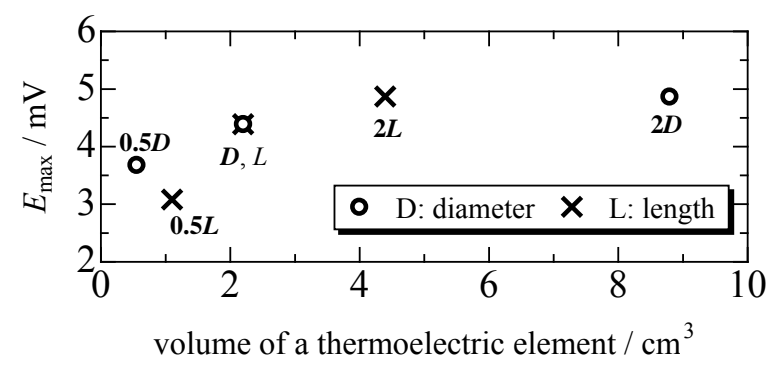

Fig.16 Maximum electromotive force against the volume of a thermoelectric element

また，素子の長さおよび直径の違いによって最大起電力に 達寸るまでの時間に変化が現れた. 図 17 に基準寸法と比較 した最大起電力に達するまでの時間の関係を示す. 寸法の変 化に対寸る最大起電力に達寸るまでの時間は, 図 15 に示し た最大起電力と同様の挙動を示し, 最大起電力が大きくなる とそれに達するまでの時間も共に長くなることが分かった.

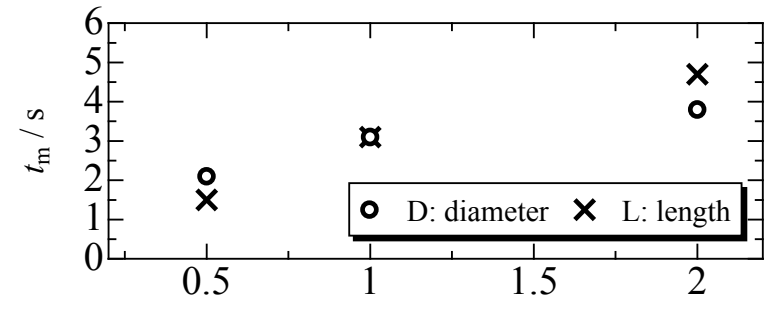

ratio of length and diameter to reference value

Fig.17 Elapse time at a peak of electromotive force against the ratio of length and diameter to the reference value

\section{4 温度変化センサの熱電素子の物性依存性}

温度変化センサを装置などに組込む際に，大きさなどの形 状に制限がある場合は，物性の異なる熱電素子で対処するこ とが考えられる. 温度変化センサの性能に関係する熱電素子 の物性值は, 熱伝導率, 比熱, 密度, ゼーベック係数であり, 最適な熱電素子を探索する際の情報として，それぞれの物性 值が温度変化センサの性能に及ぼす影響を明らかにする。 そ こで，基本形状（熱電素子の長さ $7 \mathrm{~mm}$, 直径 $20 \mathrm{~mm}$ ） と電極 や恒温水槽温度, 初期条件，境界条件を固定したまま，それ ぞれの物性值のみを 2 倍， 0.5 倍にした場合の計算を行なつ た. 起電力の経時変化について，熱伝導率の依存性を図 18 に，比熱の依存性を図 19 に，密度の依存性を図 20 に，ゼ一 ベック係数の依存性を図 21 に示寸. 熱伝導率は值が小さい 程，その他の物性值は值が大きくなる程，最大起電力は大き くなる. 図 22 にそれぞれの物性值の基淮值からの比に対す る最大起電力の関係を示寸. ここで, 熱伝導率については他 の物性值と比較するため, その逆数を用いた. 最大起電力に 与える影響は，ゼーベック係数が最も大きく，その值に比例 して大きくなる. 次に熱伝導率の影響が大きく, 比熱と密度 はある程度大きくなると, 最大起電力はそれ程変わらなくな ることが分かる. また, 比熱と密度は同じ挙動を示しており， 比熱と密度の積である単位体積あたりの熱容量に最大起電 力が関係していると考えられる.

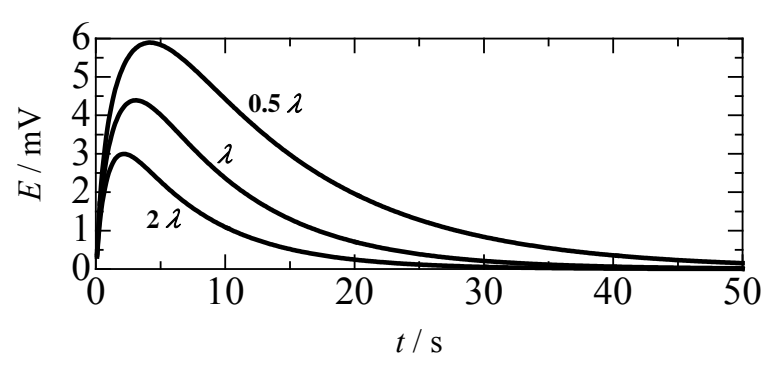

Fig.18 Comparison of electromotive force change in different thermal conductivity of thermoelectric element 


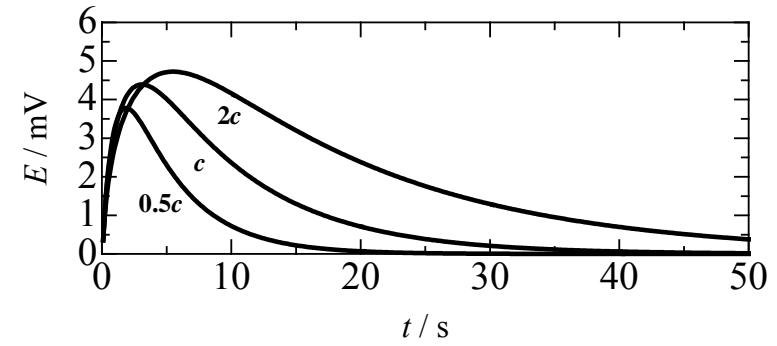

Fig.19 Comparison of electromotive force change in different specific heat capacity of thermoelectric element

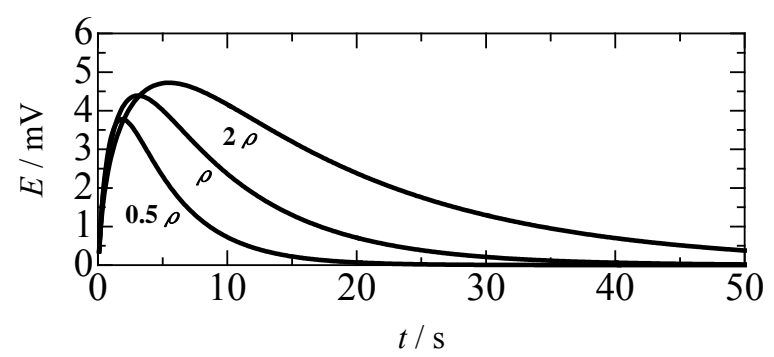

Fig.20 Comparison of electromotive force change in different density of thermoelectric element

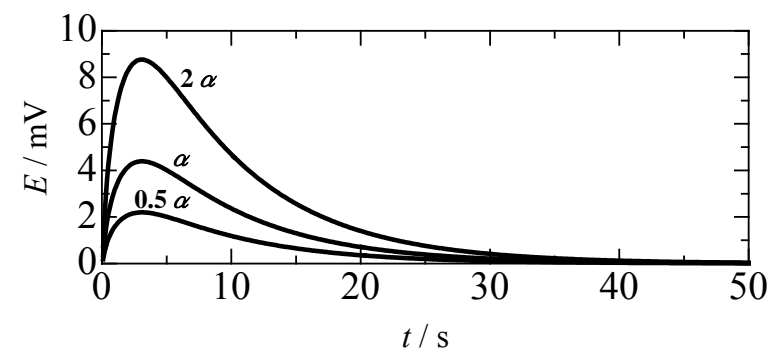

Fig.21 Comparison of electromotive force change in different seebeck coefficient of thermoelectric element

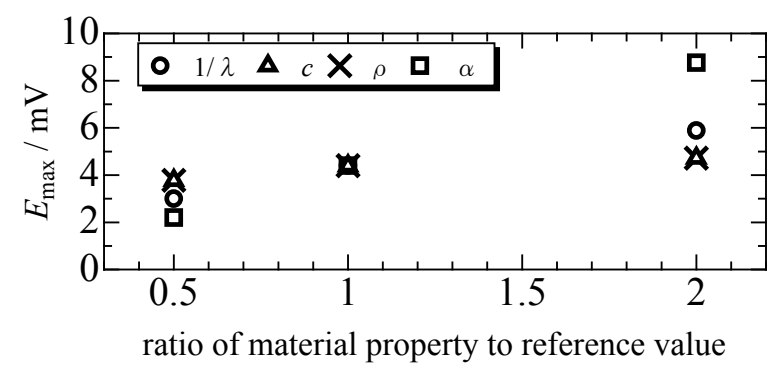

Fig.22 Maximum electromotive force against the ratio of material property to reference value

また，それぞれの物性值の基淮值からの比に対する最大起電 力に達するまでの時間の関係を図 23 示す. ゼ一ベック係数の依 存性はなく，比熱および密度に大きく依存し，次に熱伝導率の 逆数の依存性が大きかった. ゼーベック倸数以外は, 熱拡散係 数に関する物性值であり，その中でも特に比熱と密度といった 熱容量に関する物性值の影響が大きいことが分かった。

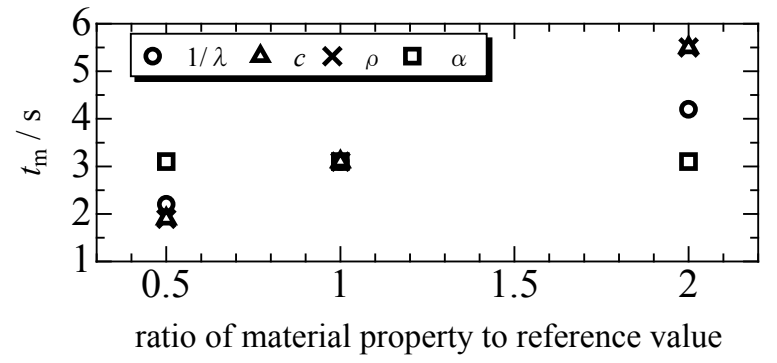

Fig.23 Elapse time at a peak of electromotive force against the ratio of material property to reference value

\section{7. 結 論}

本研究では, 熱電素子を用いた熱電温度変化センサを提案 および試作し，その動作確認と温度差に対する起電力の特性 を明らかにした．また，その特性を FEM 解析により，熱電 素子の形状や物性值に対する特性の変化について定性的に 明らかにした。

[謝辞］

本研究を遂行するにあたり，多くのご助言を戴きました東 京理科大学基礎工学部材料工学科飯田努准教授に感謝の意 を表します。

\section{参考文献}

［1］舟橋良次, 浦田さおり; 「廃熱を有效利用する酸化物熱 電発電モジュールの開発」, 応用物理, 77 (2007) 45-48.

［2］木戸長生，荒川敏和；「ペルチェ冷却式冷蔵庫」，冷 凍, 73 (1998) 65-70.

[3] I. Nishida; "Study of Semiconductor-to-Metal Transition in Mn-Doped FeSi 2 ", Physical Review B, 7 (1973) 2710-2713.

４４］安野拓也，東之弘，川原正和，铇田正雄；「FeSi ${ }_{2}$ 系熱 電変換材料及びその製造方法」，特開 2007-324500.

５］田中勝之，安野拓也，東之弘；「FeSi $i_{2}$ 系熱電変換モジ ユールのゼーベック係数の測定」，日本熱物性シンポ ジウム講演論文集，28(2007)，259-261.

［6］日本熱物性学会編；熱物性ハンドブック」，(2007）, 23，126-127，養賢堂，東京.

[Received Jun.4, 2008, Accepted Nov.13, 2008] 